\title{
The implementation of the Student Response System (SRS) Kahoot! In EFL classes and its effects on reading comprehension
}

\section{La implementación del Student Response System (SRS) Kahoot! en las clases de inglés como lengua extranjera y sus efectos en la comprensión lectora}

Joe Adrián Narváez Paguay

Universidad de Cuenca, Ecuador

adrian.narvaezp@ucuenca.edu.ec

(D) https://orcid.org/0000-0002-0787-9017

Juan José Santillán

Universidad de Cuenca, Ecuador

juan.santillan@ucuenca.edu.ec

https://orcid.org/0000-0002-4968-1332

Recepción: 07/12/2020 | Aceptación: 08/03/2021 | Publicación: 10/05/2021

Cómo citar (APA, séptima edición):

Narváez Paguay, J. A., y Santillán, J. J. (2021). The implementation of the Student Response System (SRS) Kahoot! In EFL classes and its effects on Reading comprehension. Innova Research Journal, 6(2), 1-21. https://doi.org/10.33890/innova.v6.n2.2021.1655

\begin{abstract}
Improvement of teacher-student class interaction has been obtaining greater progresses thanks to technological development with the addition of practical resources and modern facilities in educational institutions. The use of game-based response systems for enhancing language skills inside an EFL classroom has reported benefits mainly for certain particular skills like grammar and sentence structuring. In this study, the online gaming platform Kahoot! was used specifically for enhancing the reading comprehension skill through a period of nearly three months on students of A2 level from Universidad de Cuenca in Ecuador. The intervention of the Kahoot! website focused on the comprehension and remembering of specific details by means of quizzes. The research design of this study used a mixed-method based on the Hypothetico-Deductive approach to research and data collection instruments, as well as their further analysis and interpretation. Pre and posttests were used in order to compare the results before and after the methodology. The outcomes revealed a statistical improvement with favorable effects regarding the pre and posttests and also a general learner acceptance towards the stated methodology. Further research is
\end{abstract}


suggested on the use of Kahoot! for reading comprehension improvement purposes and its continuous use as a supporting tool for remembering specific details of texts, together with other subskills which could possibly be benefitted from this methodology in the field of EFL instruction. Keywords: reading comprehension; game-based response systems; student response systems; gamification; online resources.

\section{Resumen}

El mejoramiento de la interacción entre estudiante y docente ha venido obteniendo mayores progresos gracias al desarrollo tecnológico con la adición de recursos prácticos e instalaciones modernas en instituciones educativas. El uso de sistemas de respuesta basados en juegos para mejorar las habilidades del lenguaje dentro de una clase de inglés como Lengua Extranjera ha reportado ser benéfico principalmente para ciertas destrezas como gramática y estructura de oraciones. ¡En este estudio, la plataforma online de juego Kahoot! fue usada específicamente para mejorar la destreza de lectura comprensiva a través de un período cercano a tres meses con estudiantes de nivel A2 de la Universidad de Cuenca en Ecuador. La intervención de la página web Kahoot! fue enfocada hacia comprensión y memorización de detalles específicos. El diseño de investigación de este estudio usó un método mixto basado en el método Hipotético-Deductivo en base a instrumentos de recolección de datos, así como el posterior análisis e interpretación de los mismos. Pre y posttests fueron usados para comparar los resultados antes y después de la metodología. Los resultados revelaron un mejoramiento estadístico con efectos favorables en los pres y posttests y también una aceptación general hacia la mencionada metodología. Se sugiere más investigación con respecto al uso de Kahoot! para propósitos de mejora en la lectura comprensiva y su uso continuo como herramienta de apoyo para recordar detalles específicos de textos, junto con otras subdestrezas que podrían verse beneficiadas de esta metodología dentro del campo de la enseñanza de inglés como Lengua Extranjera.

Palabras clave: lectura comprensiva; sistemas de respuesta basados en juego; sistemas de respuesta de estudiantes; gamificación; recursos online.

\section{Background to the study}

Basic literacy can be regarded as essential for school achievement as well as for, in the greater sense, a country's well-being (Kutner Greenberg, Jin, Boyle, Hsu \& Dunleavy, 2007). Some of the main aspects that facilitate better reading instruction for improving literacy include addressing key components such as phonemic awareness, phonics, fluency, vocabulary, and comprehension (National Reading Panel, 2000) along with the provision of pedagogical strategies which target lower and higher-order processes (RAND Reading Study Group, 2002; Shanahan, 2006).

An examination carried out by the British Council for policy, perceptions and influencing factors of English Learning in Ecuador in 2015, revealed that among the English learning motivations, the survey respondents were asked about why their English reading skills were lacking. The respondents (ranging from 16 to 44 years old) came from various income levels, occupations, and interests. 
The largest share of respondents (45\%) cited their own responsibility for not reading frequently enough. Lower percentages presented difficulties such as not having been studying English for a long time, the poor curriculum design in the educational system, and weak teachers (Education \& Intelligence, 2015).

In terms of the study's background, the Ecuadorian higher education context is still regarded as deficient, and despite the governments' attempts in addressing this problem, English as a Foreign Language (EFL) students still present considerable lack of proficiency (Cronquist \& Fiszbein, 2017).

\section{Language Learning Through Online Resources}

It is imperative for a teacher who needs to engage their students, to logically utilize viable alternatives in order to encourage the attention on texts which normally have many words, but few images. Technology for purposes of engagement and motivation has the potential to facilitate the achievement of academic and professional objectives through self-generated thoughts, feelings, and actions that are planned and cyclically adapted to the attainment of personal goals (Zimmerman \& Schunk, 2011).

On this account, Qiu and Bai (2013) express the importance of games with their multiple formats for presenting information including motionless or animated text, pictures, movie segments, video clips, and audio information. Furthermore, when teaching language subjects specifically, Wells (2011) declares that games can particularly alter on-task behavior, as well as word acquisition and content understanding.

\section{Reading Comprehension}

As stated by Mikahilov (2001), reading is a complex cognitive process of decoding symbols in order to obtain meaning which can be used as means of language acquisition, communication, and sharing of information. According to this author, a good reader's job is not just to think about the contents communicated by the writer, but also about the messages that can be collected and stored into the students' schemata, because in the reading process, schemata and language skill must be used to reveal the message of text. From a socio-cultural perspective, the focus on schemata as a source of variability (Reynolds, Taylor, Steffensen, Shirey \& Anderson, 1982) prompts speed, accuracy, and recollection of culturally familiar material.

Consequently, the comprehension can be seen as resulting from filtering process of the information gathered from a person's foundation of knowledge and belief (Shanahan, 2005). The author states that it is also necessary for a given text to be logically well-structured in order to make the reader think about the writer's message by making inferences.

In her point of view, Snow (2002) states that the words extracting and constructing are used to emphasize both the importance and insufficiency of the text as a determinant for reading comprehension.

She goes on to state that this process entails three main elements: the reader, who is doing the comprehending with all their capacities, abilities, knowledge, and experiences; the text that is 
to be comprehended, and the activity where purposes, processes and consequences are associated with the act of reading.

\section{Reading comprehension subskills}

Gunn, Smolkowski, Biglan, Black \& Blair (2005) state that "fluent word recognition allows the reader to allocate increased attention to key comprehension processes" (p. 70) which also involves meaning-making and meaning-relating. This assumption gives clarity on the importance of familiarizing students with reading subskills from an early age of their schooling progress to help them connect their previous knowledge with their comprehension of written texts.

According to Grabe (2009) the purposes of reading include searching for information, reading for quick understanding, integrating information, evaluating, general comprehension, and more. The general definitions are mentioned by this author as follows: skimming (reading for gist) means reading quickly over a text to get the main idea. Scanning (reading for detail) is reading a text to find specific ideas. Selective reading is regarded as a combination of reading and research with a specific purpose, instead of running through a text which may not necessarily have a useful significance as Beckford (2018) clarifies. In concordance with the latter, selecting the right type of books to read and not only sections in them is another important part to select only the specific information needed.

The findings by Mikahilov (2001), Reynolds, Taylor, Steffensen, Shirey \& Anderson (1982), and Shanahan (2005) are yet again supported by the Affective Filter Hypothesis by Steven Krashen (2009) where the inference is that the success of learning (or reading specifically) can be real if the variables are applied and utilized accordingly by learners.

The importance of considering reading skills as a foundation for knowledge and learning relies heavily on Krashen's Reading Hypothesis (Krashen, 1994; 2003, 2004, 2018). He describes reading as decoding comprehensible input that results in the acquisition of literacy-related aspects of language (Krashen, 2018).

\section{Technology and Reading}

Mobile Assisted Language Learning (MALL) is a subdivision of Computer Assisted Language Learning (CALL). As mobile technologies have advanced, so have interventions for enhancing language education. The term MALL came into focus as an emerging query for language learning through technology. Research suggests that it provides language learners with rich, real-time collaborative experiences in and out of the classroom (Duman, Orhon \& Gedik, 2014). Among the assets which MALL features, there is the customization of learners' environment, the encouragement of self-study, the providing of experience outside of the classroom, the boosting of the students' morale, the making of the process of learning more interesting and joyful, and the flexibility and access to all the learners (Kondal \& Prasad, 2016). These authors state the association of students to the web through mobile devices, which have become an essential part of life, and how these technologies "provide wider possibilities with better 
learning characteristics and interventions for higher education focused on learner mobility and personalization for a lifelong knowledge" (p. 112). More recently, Cheung \& Slavin (2012) argued about the importance of technology for making the most of students' engagement by providing them with meta-cognitive strategies for text comprehension and other reading skills.

Having in consideration that there is great potential for students to become motivated by their own learning progress through the focused use of technology, research also revealed that selfregulation interventions directed for reading comprehension were particularly beneficial for individual learning achievement (Pintrich, 2003). It is also important to address on this particular matter since the self-regulation framework also offers a base for reading comprehension, with emphasis on higher-order processes working together during information processing (Lysenko \& Abrami, 2014).

\section{Kahoot! and Reading}

In a study carried out by Hou (2018), the author researched about the training of students for using Kahoot! to provide answers about questions related to their different reading literacy materials. The author's research adopted 16 of 21 questions developed by Wang (2017) to discover learners' perception towards teaching through SRS's, covering teacher interaction, engagement, self-efficacy, and degree of learner satisfaction at the beginning of the semester (pretest) and at the end of it (posttest).

MALL (Mobile Assisted Language Learning) tasks were used mainly to assess students' comprehension and to enhance their participation and attention on reading through Kahoot!

It was concluded that by using Kahoot! both teachers and students could notice how well the reading materials were assimilated, and it also inspired students to think actively and critically via questioning and thus, increasing their motivation on English learning.

As to the most appropriate time to introduce media in a classroom, Chotimah and Rafi (2018) mention four specific moments to do it: (1) before learning the concept so that students compare the topics and recall quick reference examples. (2) After a brief introduction but before learning the concept to provide students with information of what the media is about and what information to focus on. (3) After learning the concept to help learners in developing their analysis to apply what they are learning. (4) Before and after to help developing student understanding of complex topics. The last approach subdivides by using the media before the discussion to have a general idea and guide them through a description or discussion of the topics. For the present study, a systematic approach of prereading and post reading strategies was employed.

Chotimah and Rafi's (2018) experimental study aligns with previous assertions by Arsyad Azhar (2005) where the use of Kahoot! claimed to increase students' attention on the questions given since the time to answer them is limited. The authors of the experimental study conclude that for college students who used the media Kahoot! performed with better achievement than the students who only used the textbook.

Regarding the relation of Kahoot! in higher education (Lin and Kaur 2018) for inducing intrinsic and extrinsic motivation, the results were overall positive aligning with Zarzyeka- 
Piskorz's (2016) study which claimed that with the use of gamification, the learning process becomes more engaging. Lin and Kaur (2016) indicate that 98\% of their students asserted a higher motivation level when using Kahoot! similarly with the extrinsic motivation, which was displayed through the students' competitiveness during the Kahoot! sessions and their eagerness to participate and win the game. The authors went on to state that Kahoot! fosters and reinforces learning with regards to theoretical frameworks, analysis models, media concepts and media language features, and media writing techniques. Kahoot! has proven to be a key element in supplementing students with the comprehension of reading literacy materials (Cutts, 2004), improving concentration (Chiang, 2016) and necessarily comparing the learners' performance and satisfaction of the methodology at the end of their treatments (Hou, 2018; Lee, 2017; Yang, 2017, Wang, 2016; Ismail \& Mohammad, 2016, Wichadee \& Pattanapichet, 2018; Medina \& Hurtado, 2017; Wash, 2014; Lin, 2016).

In addition, research has proven that Kahoot! is valuable in complementing learning as a formative assessment tool for medicine students due to its practicality (Ismail \& Mohammad, 2017).

\section{Research questions}

What is the effect of using the Student Response System Kahoot! intended for the development of reading comprehension skills of A2 level students at Universidad de Cuenca?

Which are the individual perceptions towards using the Student Response System Kahoot! obtained through a focus group of students at the end of the treatment?

\section{Methodology}

\section{Research Method and Variables}

The study was an empirical interventional paradigm that looked to estimate its impact on a group of A2 EFL level students to determine the effect of Student Response Systems (independent variable) as a reading comprehension evaluation tool for fostering students' reading for detail performance (dependent variable). This study is framed under Mixed-Method Research. It aimed at a thorough examination of data by means of using Mixed-Methods, since the behavior of the two paradigms (quantitative and qualitative) would generate greater EFL knowledge in the Ecuadorian higher-level education background practice.

This Mixed-Method research was labelled under a quasi-experimental quali-quantitative study for collecting data, and it had one intervention group. This type of method is considered as pragmatic, because the decisions concerning design are in concordance with the suitability of the purposes and objectives of the study (Gheitasi \& Lindgren, 2015).

\section{Case study research}


This study also falls into the categorization of Case Study Research. The context for this particular study is higher-level EFL education in Cuenca, Ecuador, due to the availability, proximity, and ease-of-access features which facilitated the collection of information for the researcher. About this assertion, a case study research aims at the in-depth study of a unit of analysis from the research universe as Bernal (2010) stated. Such unit of analysis can incorporate a single individual, a group of participants, an entire class, or a complete institution to explain causal links in real-life situations (Mackay, 2010).

The main sources of data were the individuals who come from a specific part of the unit of analysis, together with the documented information that they produced. Concordant with the previously mentioned features of case study research, this study analyzed the influence of Kahoot! on the development of reading comprehension skills in a particular group (case) of EFL students at Universidad de Cuenca.

\section{Population and sample}

The researcher was assigned with an initial group of 21 participants, men and women coming mainly from the Economy, Marketing, and Business Administration majors at the Economy Faculty of Universidad de Cuenca, Ecuador. The students were undergraduates who were taking their final English level in concordance with the institution's policies. This unit of analysis for the research study was eventually composed of 6 men and 13 women with ages ranging from 19 to 26 years old. These native Spanish participants attended classes on a normal basis, and agreed to participate in the study. The selection of the mentioned unit was in strict concordance with the research background for this study and the practicalities of convenience sampling such as easy accessibility, geographical proximity, availability at a given time, the willingness to participate included for the purpose of the study, as well as its applicableness to both quantitative and qualitative studies as Etikan (2016) stated.

\section{Treatment}

The content taught on a $3^{\text {rd }}$ level credit course at the Language Department of Universidad de Cuenca is based on the Common European Framework (CEFR) and its overall A2 level expected proficiency. The researcher sought to attest that the proficiency of the learners was sufficient, considering that most of them had previously approved the first two levels.

In accordance with these characteristics, there was a clear orientation with the purpose of this study, because the learners could comprehend and work with the pre-selected stories, since they matched the mentioned A 2 references. The reading comprehension activities were grounded on this framework considering the subskills which were specifically evaluated for this study: Reading for Gist, Reading for Detail, and Selective Reading. The researcher had to determine which of these skills presented the lowest score by means of applying a pretest.

The A2 pretest employed originated from TELC (The European Language Certificates) language tests organization website, which strictly considers the goals of the Council of Europe for offering tests with reliable international verified standards. Being a free-access exam that can 
be downloaded, there was no inconvenience for the researcher to cope with copyright issues, nor to select the reading sections which were intended for creating the quiz and uploading it to the Moodle platform "E Virtual". Each subskill consisted of four questions and a total value of 3.33 points. Additionally, the scoring of $6 / 10$ was established by pondering the original instrument, considering that the participants who scored less than 6 points over 10 did not have enough skill development to reach the desired A2 level; therefore, students with scores between 6 and 6.9 points passed the test; those with grades ranging from 7 to 7.9 points had a satisfactory performance; participants who scored from 8 to 8.9 points had a good performance, and those that obtained 9 to 10 points had a very good performance.

The overall results of the reading comprehension pretest presented a rather low score of 4.93 over 10 points regarding the previously mentioned reading skills, making the students unable to reach the A2 level satisfactorily at the beginning of the treatment. With the help of the pretest it was evident for the researcher that there was a high dispersion among scores and only 3 of the 18 students reached the A2 level successfully. The results of the pretest presented a higher performance regarding the Reading for Gist and Selective Reading sections. In contrast, a lower performance on the Reading for Detail section was noticeable. The importance of improving the Reading for Detail subskill was the focus of the research after comparing the scores of the pretest among these subskills.

Considering these preliminary outcomes, it was then apparent that if more attention was directed to the details of a text, students would be more attentive on being able to evaluate, comment on or clarify the peculiarities of a text as Gilmanova, Nikitina, \& Khasanova (2016) pointed out. As reference, the scope of their research was focused on the use of authentic literature in the process of teaching EFL reading, and for this, it was considered that Reading for Detail was the most significant subskill as it requires the combination of other previously learned skills which would be useful for further interpretation.

In consideration of these data, the researcher used the selected SRS Kahoot!, which was intended as a reading evaluation tool for progressively accompanying the content of the level and improving the Reading for Detail skill's overall performance. Specifically, Kahoot.com was the site where the quizzes with multiple-choice questions about specific details of the selected texts were customized. These quizzes were displayed from a computer by means of a projector to help keeping track of the individual scores of the students during each intervention. The reading material from where the questions for this interactive platform were created, came from the second edition of Longman's "True Stories in the News, a beginning reader" by Sandra Heyer (1996) due to its newspaper format stories which aligns with the outcomes of the CEFR scales for reading comprehension for A2 level. The stories included in the textbook initiate with simple short texts and progressively develop to be more complex and contain more vocabulary. Before each session in the particular quiz game, each student had to predict about some elements prior reading each story. These elements included: questions about the people, places, or objects depicted in the pictures before each story, inferences about the content of the story, and predictions for the ending. After reading each story in detail, the researcher's role was of conducting the students to an external website (kahoot.it) for obtaining a unique accessing code and playing each pre-designed quiz individually on their device. 


\section{Data collection}

The A2 mock test which was adapted for pre and posttest was developed by TELC (The European Language Certificates) education organization that offers language tests based on international standards which align with the Common European Framework of Reference for Languages of the Council of Europe. It contained all the aimed reading comprehension subskills to be evaluated, and it granted free access with no issues regarding copyright.

All the information gathered via pre and posttests focused on statistical analysis to report the findings. It was obtained by uploading the content of the Reading sections needed from the TELC A2 exam. This data and results were collected and kept via "E-virtual", the Moodlebased platform which Universidad de Cuenca holds as its main digital platform for academic assignments.

In order to examine students' perceptions and attitudes towards the technological strategies used in class, a focus group interview was carried out at the end of the treatment. The questions for the interview had been previously piloted with a different group of students from the same level who were also taught English by the same researcher at the time the study took place. This endowed the instrument with validation. A list of the questions used for the focus group can be found in Annex 1.

The focus group included six participants, randomly selected by means of a randomizer online tool. As suggested by Morgan (1997), such procedure ensures more reliable results, because it gives the participants the opportunity to raise more facts and arguments.

The guiding questions for the focus group interview sought to identify the students' perceptions about the interest each story rose, their format, the overall methodology, favored features of Kahoot!, their own thoughts about variation on their reading skills, and suggestions or recommendations for future use.

\section{Data processing and analysis}

The statistical processing of data was done in the SPSS 25 program by an expert statistician along with Shapiro Wilk's test for data behavior. For the editing of graphics and tables, the program Microsoft Excel 2019 was used. The results of levels and produced changes are shown through absolute frequencies, as well as central tendency and dispersion measures. The analysis of information was carried out by using inferential statistics which allowed to compare the pre and posttests. To compare the pre and post intervention of students' statistical results, a T-test was used for assessment of the outcomes.

The transcription of results from the focus group interview was processed by means of the Microsoft Word software, which allowed an initial and final editing of the information obtained. The answers from this group were analyzed using the Atlas.ti 7.5.18 software and the categories of analysis emerged in an empirical manner, based on the questions that the researcher particularized and the analysis itself. 
The process encompassed the identification and codification of specific quotes arousing from the questions and answers included in the focus group questionnaire. The categories of analysis that were considered as codification procedure by the researcher at the Atlas.ti software were: motivation, interest, methodology, acquisition of new vocabulary, along with positive and negative aspects about Kahoot!. Such categories emerged from considering the outcomes of similar studies were these elements were found.

The discussion of the results was done in a question-to-question format that allowed perceptual analysis and the inclusion of pertinent quotes. To guarantee confidentiality and anonymity, the names of the participants were omitted. Finally, discussion progressed with the presentation of the interview results.

\section{Results and discussion}

\section{Analysis of Pretest results}

Data behavior according to Shapiro Wilk's test resulted in not normal $(\mathrm{p}<.05)$ for which the non-parametrical Wilcoxon test for related samples was employed. The results showed that prior to the intervention, the students had oscillating scores between 0 and 3.32 for each subskill, being Reading for Gist the most consistent due to an average performance of 2.49 ( $\mathrm{DE}=0.78$ ), followed by Selective Reading ( $\mathrm{M}=1.27 ; \mathrm{DE}=0.58)$. Finally, Reading for Detail was the weakest subskill in this group of students, with an average score of $1.16(\mathrm{DE}=0.5)$; in every case, high dispersion of data was registered, which implies heterogeneous behavior. See Table 1.

\section{Table 1}

Pretest results

\begin{tabular}{lllll}
\hline & Minimum & Maximum & Mean & SD \\
\hline Reading for Gist /3.33 & 0.83 & 3.32 & 2.49 & 0.78 \\
Reading for Detail /3.33 & 0.00 & 2.49 & 1.16 & 0.55 \\
Selective Reading /3.33 & 0.00 & 2.49 & 1.27 & 0.58 \\
Total pre test /10 & 2.50 & 7.50 & 4.93 & 1.41 \\
\hline
\end{tabular}

The global score oscillated between 2.5 and 7.5 with a mean of $4.93(\mathrm{DE}=1.41)$ having the students in a general state of reading comprehension deficiency.

\section{Analysis of the Posttest results}

In light of these results, Kahoot! was applied for strengthening the Reading for Detail subskill. After its intervention, there was an average difference of 0.17 points in the Reading for Gist subskill, without representing a significant change ( $\mathrm{p}=.248) .10$ participants did not present any variation, 7 participants had a positive change, and 2 had a negative change. The Reading for Detail subskill, had an average increase of 0.53 points, representing the greatest progress subskill $(\mathrm{p}=.014)$ with an increase of successes in 10 participants; finally, the Selective Reading subskill 
showed an average progress of 0.39 points. In spite of having 11 participants with increase of successes in this section, no significant changes were found $(\mathrm{p}=.09)$. Details in figure 1.

\section{Figure 1}

Change post - pretest

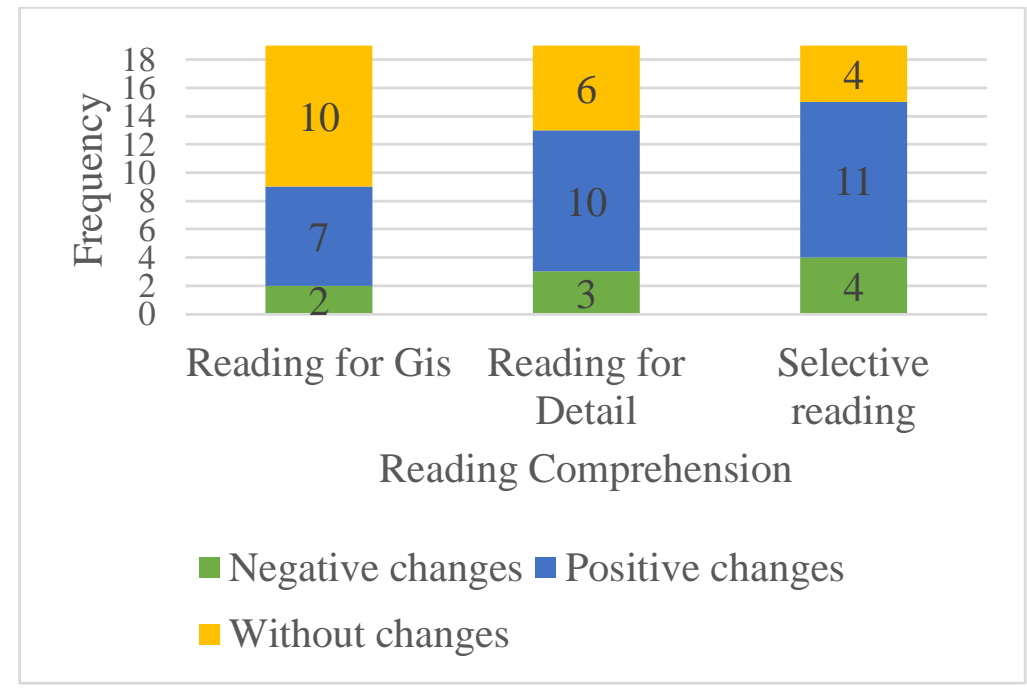

The posttest results are shown in table 2. There, it can be observed that Reading for Gist was the most developed reading comprehension subskill $(\mathrm{M}=2.66 ; \mathrm{DE}=0.76)$, followed by Reading for Detail ( $\mathrm{M}=1.69$; $\mathrm{DE}=0.66)$, and Selective Reading $(\mathrm{M}=1.66$; $\mathrm{DE}=0.92)$. In spite of registering a high dispersion of data, the results were inferior compared to the pretest, which implies that after the intervention, the students presented similar trends. Aside from that, it was generally found that every skill reached at least half of the maximum score.

\section{Table 2}

Posttest results

\begin{tabular}{lllll}
\hline & Minimum & Maximum & Mean & SD \\
\hline Reading for Gist /3.33 & 0.83 & 3.32 & 2.66 & 0.76 \\
Reading for Detail /3.33 & 0.42 & 2.91 & 1.69 & 0.66 \\
Selective Reading /3.33 & 0.00 & 2.49 & 1.66 & 0.92 \\
Total pre test /10 & 2.50 & 8.33 & 6.03 & 1.67 \\
\hline
\end{tabular}

After the intervention, the results for reading comprehension oscillated between 2.50 and 8.33 with a mean of 6.03 ( $\mathrm{DE}=1.67$ ) obtaining the required skills needed to meet an $\mathrm{A} 2$ level with a significant average increment of 1.37 points by student $(\mathrm{p}=.029)$. In Figure 3 it can be observed that 7 students had the necessary competences (Pass $=2$, Satisfactory $=4$, and Good $=1$ ), whilst the remaining 12 (deficient) presented an average score of $5.38(\mathrm{DE}=1.74)$ consisting of a very near 
to the minimum value, and denoting that the controlled use of Kahoot! for incrementing the Reading for Detail subskill performance results accounts as a consistent tool.

\section{Figure 2}

\section{A2 level category posttest}

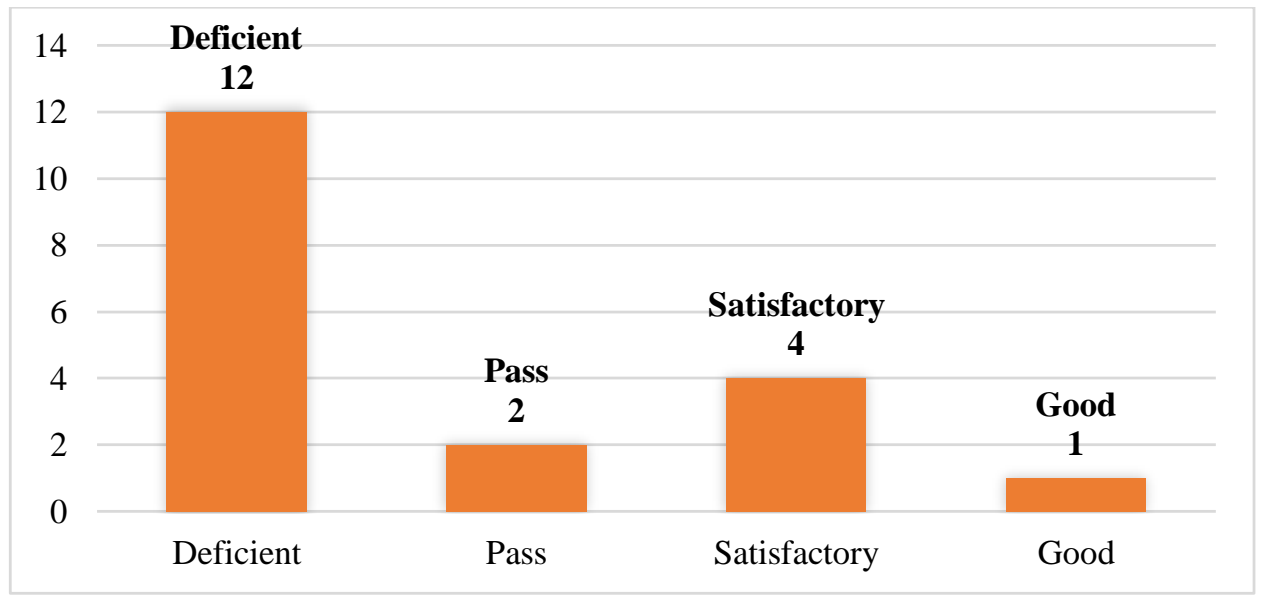

\section{Interpretation of focus group interview}

The focus group interview was carried out at the end of the treatment of this study and the majority of students agreed on the positive stimulus that Kahoot! added to their own learner experience. Categories like motivation, interest, vocabulary acquisition, dynamics of the game and interactivity are present in it.

In the first question, the researcher wanted to have a clearer take on the general interest that the stories represented for the participants; the answers confirmed that the stories aside from being interesting, also allowed them to learn new vocabulary. Three out of six participants expressed their agreement. With this finding one can expect that the general understanding that students present towards unknown texts without going deep into details as well as maintaining interest on them (Gilmanova et al., 2016), is existent with stories which come from realistic contexts, encompass the Reading for Gist subskill and their development implies further attaining of vocabulary and information.

In the second question, two of the six participants agreed that the format was suitable and one of them mentioned the conciseness of the stories and the clear message within their few lines. Similarly, with the study carried out by Gilmanova et al. (2016), a participant addressed environmental protection issues, aligning with the opinion of maintaining the practicality of using technology instead of overusing paper.

Regarding the dynamic aspect addressed in the third question, there were three students who agreed that Kahoot! featured this characteristic; two others mentioned that motivation improved. The participants in the study felt comfortable about using a digital familiar approach as 
they come from an era where communication and interaction with information is always available, or they feel safer in this kind of game-based learning environment (Licorish et al. 2018). With the previous assertion it could be said that the students accepted the methodology of Kahoot! in the classroom. It can be implied that students from the digital era benefit from the numerous aids of online resources. While Kahoot! is a multimedia assessment means, it also represented an innovation instrument, bringing into line studies where it accounted as a successful assessment tool for teachers (Dellos, 2015; Ismail \& Mohammad, 2017; Medina \& Hurtado, 2017).

The participants also remarked the importance of having technology inside of the classroom since there was account on the versatility and adaptation in education, as well as the positive competence environment that Kahoot! Stimulated.

Regarding the fourth question, it was also mentioned by another participant that Kahoot! did not count as a traditional methodology for him, and that it overall made learning English fun. These two assertions bring into line the ludic competitive environment that Kahoot! induced, as well as being entertaining and allowing creativeness on the participants' side. One can corroborate Huang's (2015) study, where the author specifically compared the development of vocabulary against traditional pen and paper and text board methods (PPT), and the participants who underwent the technology-based treatment outscored the traditional group.

As of the fifth question, the lack of initial vocabulary and rote memorization of words were mentioned by two participants, who had trouble internalizing this information in a short period of time. To lessen this difficulty, the need for an inquiry-based methodology such Kahoot! induced an intensified alertness regarding the vocabulary used in each story and its possible connections to real-world definitions (Young, 2005). While two of the participants mentioned the struggle that the methodology represented for them, there was a positive overall reception because of the interactive aspects of the game.

Seemingly, the answer from one student in the sixth question denotes interest in working with Kahoot! because there were no initial expectations on what the stories were going to be about, nor the methodology itself. The lack of vocabulary was not a barrier to work with the comprehension of the story as the second participant affirmed. The process that the participants embraced was of piecing together the information composed of content through active investigation and recognition of words (Subramaniam, 2012). It can be deduced that having the participants on an active mode of lexical exploration benefitted their involvement and retention of key elements from the stories.

In the seventh question, a participant declared the importance of skimming the story before actually reading it. It is clearer that two participants preferred using Kahoot! due to its own particular game modality, as well as the actual steps for a better reading comprehension that the researcher employed prior answering the particular quizzes. Engagement of audiences, problem solving, and elicitation of game-like thinking are features of gamification which according to Pede (n.d.) stimulate other aspects such as independent and collaborative learning. These aspects were present in the study and permitted a continuous practice of skills. 
Finally, at the eight question, another student suggested the use of similar applications for other skills like listening, writing, and speaking.

Two students became aware on the potential that Kahoot! includes for further studies regarding other English skills and how these could be enhanced. The opinions from the focus group regarding this last inquiry match this criterion, as the opinions of two participants remarked the possibilities in which Kahoot! could be further used in other EFL scenarios. All the participants in the study gave positive feedback regarding the use of Kahoot! The game environment was a great part of why the participants enjoyed the platform. This finding is supported by other studies which comprise motivation, interest, and generally making English classes more fun (Dellos, 2015; Ismail \& Mohammad, 2017; Licorish et al., 2018; Medina \& Hurtado, 2017; Wang \& Lieberoth, 2016; Zarzycka-Piskorz, 2016). The qualitative section of the research establishes a precise outcome of the observations obtained from the participants after the intervention. In their general view, the modality and transfer of information that Kahoot! prompted, was gradually adapted and acknowledged to their own English skills.

\section{Discussion}

The statistical analysis and comparison of the pre and posttests complements the qualitative post-intervention interview results previously addressed. These demonstrate that both qualitatively and quantitatively, the use of Kahoot! had constructive effects on the participants' reading comprehension subskills. The scores were esteemed between $0-0.33$ for both pre and posttests. The findings are supported by the $\mathrm{p}$ value employed to measure the results of the pre and posttest interventions, consisting of less than .05. Each of the assessed reading subskills presented half of the total pondered score, and it can be noted that Kahoot! does not merely work for evaluation means, but it helps joining students' previous knowledge with relevant new schemata as the Reading for Gist subskill results illustrate.

The participant who had the lowest score at the Reading for Gist section presented 0.83, but the overall scores presented a mean of 2.50 over 3.33 implying that the Reading for Gist skill was the most proficient Reading subskill among this group of students. It is relevant to mention that the Reading for Gist skill may be accounted as elementary, because it is necessary to deal with any unknown text at the very first stage to understand its genre, general purpose, and main idea (Gilmanova et al., 2016).

The skimming aspect that Reading for Gist indorsed was evident at the pretest. The standard deviation for the Reading for Gist section is 0.78 with respect to 2.49 , suggesting that all the participants had a very similar behavior in this section. It is noted that since Reading for Gist counts as one of the elemental strategies that become developed together with skimming, scanning, and predicting, the participants of the study also relied on this background knowledge to fulfill the pretest.

On the contrary, the Reading for Detail general score represented 1.16 over 3.33 at the pretest results. Such outcomes reveal that the background knowledge and memorization skills of the participants to understand new texts was deficient prior to the study. About this, the low scores 
aligned significantly similar to the previously mentioned research carried out by the English Proficiency, EF (2019) where proficiency in Azuay presented a general low level of 50.23/100, adding to the fact that the practice of remembering key details and information about English texts was merely absent.

Similarly, the Reading for Detail section presented a standard deviation of 0.55, which in respect to its mean of 1.16 represents almost half of the participants showing disperse data, illustrating the fact that for a more thorough comprehension of a text, it takes a greater background knowledge regarding vocabulary and retention of information.

As the results showed, there were participants with either very high or very low scores. At the general scheme, the participant with the lowest score obtained 2.50 over 10 and the participant with the highest score obtained 7.5 over 10 .

There was a global deficient proficiency in the Reading Comprehension skill regarded for an A2 level which represented 16 of the 19 participants unable to properly grasp the language presented in the stories. See Figure 1.

Similarly, at the posttest, the results from the Reading for Gist section still accounted it as the most developed reading subskill. It is denoted that after the treatment, the participants had similar behaviors. The oscillation of results between 2.50 and 8.33 obtained a mean of 6.03 $(\mathrm{DE}=1.67)$, successfully achieving the skills necessary for A2 level with a general increment of skill proficiency in each student. It was acknowledged that the addition of Kahoot! to the course of learning indisputably affected the perception in which students constructed their schemata (Reynolds et al., 1982) because its visual features surrounding the main points conveyed through text, permitted them not to only think about the contents; students could also reflect about the message through the practice of language skills. See Figure 3.

As mentioned before, English texts have certain particularities which can be interpreted according to the learner's experience, evaluated, and elicited about their meaning with a prior sufficient knowledge plus the combination of other subskills (Gilmanova et al., 2016). The responses from the focus group represented the need of new vocabulary for comprehending the stories, as well as memorization of words. It encompassed the practice of reading and more particularly, addressing the details by means of a methodology that incorporated interactive quizzes provided by Kahoot!.

Kahoot! indorsed the necessary attentiveness about the vocabulary used in each story, supporting the learning of real-world definitions and their further practice, bringing Young's (2005) statements on this particular into line.

About the effectiveness of Kahoot! for improving language learning regarding affective factors such as attention, participation, and feeling, the participants' opinions at the focus group interview aligned with previously reported literature on the subject were this SRS appears as a tool for stimulating these from a competitive environment perspective (Bicen, 2018; Dellos, 2015; Ismail \& Mohammad, 2017; Licorish et al., 2018; Zarzycka-Piskorz, 2016). 
It is elucidated that the notion of digital natives reaps innumerable benefits of being online, including taking quizzes through a multimedia such as Kahoot! even if it involves assessment. Such results represent a great influence of a game-based technique which features factors of attitude and motivation; aspects which added up in great part of the answers coming from the focus group interview, where acceptance towards the methodology was prominent.

In summary, the controlled use of Kahoot! does allow to improve attention, awareness, motivation, and on a more specific level, allows a better learning environment. In result, it permits the enhancement of the Reading for Detail subskill by working together with other subskills pertinent to English learning such as fast reading, memorization, and vocabulary acquisition for instance.

\section{Conclusions and Recommendations}

The present study sought to facilitate the language learning process by using Kahoot! to aid in the comprehension of details in specific texts. Immediate goals and objectives were part of the stimulus which the quizzes from Kahoot! activated in each session, reinforcing positive conducts for achieving them (Lieberman's, 2006). All these efforts conveyed through logicallystructured patterns which led to make the reader think about the message qualities that were being communicated in the mentioned texts. This assertion aligns with the importance of having intrinsically-motivated readers who learn to use higher-level strategies like predicting and comprehending above word recognition.

There is great part of academic failure coming from the lack of intrinsic motivation on the learners' side. Its scarcity associates with the engagement and updated quality education that an institution needs to deliver, since it encourages reflection on the learners' side in order to take action (Wolf-Wendel, Ward \& Kinzie, 2009). It is important to address on the constructive principles which a methodology such as the one presented in this study embraced.

Lee (2008) accounted on the Processing Assumption Theory which lets the readers select the words they are going to adapt to their schemata through a visual channel. Kahoot! precisely featured the mentioned channel. Through its adaptation, the results of the study promoted greater reading knowledge, as well as enjoyment and retention of information.

Ecuador's English proficiency level resides and continues on lower levels, and the importance of making students self-aware of the capabilities that online resources facilitate is always at the hands of instructors who need to adapt such methods to keep motivation ahead. This last factor had to be emphasized in various sections of the present study since authors like Hou (2018) and Bicen \& Kocakoyun (2018) stated that the influence of SRSs together with satisfaction and interest count as a relevant key to academic formation and also promote students in becoming ambitious for success.

As a practical aspect, it is recommended that the future activities would continue to be oriented for students to think, as it would make learning more significant. It would be imperative 
to use Kahoot! for consolidating material reviewed during a process of learning. Finally, tracking each session's immediate feedback results throughout the study with Kahoot! may bring significant data to be measured by the researcher at the end of the treatment. It will maintain students focused on their individual advancement.

\section{Bibliographic References}

Syad Azhar (2005). Function and Benefits of Learning Media, 15-16. June 13, 2018, from https://educationlearning.wordpress.com/2009/01/16/function-and-benefits-of-learningmedia/

Bernal, C. (2010). Metodología de la Investigación, (3ª ed.) Bogotá, Colombia: Pearson

Bicen, H. \& Kocakoyun (2018). Perception of Students for Gamification Approach: Kahoot as a Case Study. iJET, 13, 72. http://dx.doi.org/10.3991/ijet.v13i02.7467

Cheung, A., \& Slavin, R. (2012). How features of educational technology programs affect student reading outcomes: a meta-analysis. Educational Research Review, 7(3), 198- 215. http://dx.doi.org/10.1016/j.bbr.2011.03.031

Chotimah, Ima Chusnul, and Muhammad Farhan Rafi. 2018. "The effectiveness of using kahoot as a media in teaching reading. ” Jurnal ELink 5(1):19. https://doi.org/10.30736/ej.v5i1.44

Cojocnean, D. (2016). Factors determining students' low usage of mobile tools in their English vocabulary learning. Porta Linguarum, Monograph, 1, 31-43.

Cronquist, K. \& Fiszbein, A. (2017). English Language Learning in Latin America. Retrieved from https://www.thedialogue.org/wp-content/uploads/2017/09/English-LanguageLearning-in-Latin-America- Final-1.pdf

Cutts, Q., Kennedy, G., Mitchell, C., \& Draper, S. (2004). Maximizing dialogue in lectures using group response systems. CATE

Dellos, R. (2015). Kahoot! A Digital Game resource for learning. International Journal of Instructional Technology and Distance Learning, Vol 12 (4), 49-52.

Duman, G., Orhon, G., \& Gedik, N. (2014). Research trends in mobile assisted language learning from 2000 to $2012 . \quad R e C A L L, \quad 27(2), \quad 197-216$. https://doi.org/10.1017/S0958344014000287

EF EPI (2019). EF English Proficiency Index - EF Education First. English and Society. Retrieved from: https://www.ef.com.ec/epi/regions/latin-america/ecuador/

Gheitasi, P. \& Lindgren, E. (2015). Broadening the understanding of the language classroom: Mixed Methods. In Lindgren, E. \& Enever, J. (Eds.), Språkdidaktik: Researching Language Teaching and Learning (pp. 21 -30). Umeå: Umeå University. http://urn.kb.se/resolve?urn=urn:nbn:se:umu:diva-107666

Gilmanova, A., Nikitina, S., \& Khasanova, N. (2016). Using authentic literature to teach reading at EFL classes. (2016), 8. http://www.ijhcs.com/index.php/ijhcs/index

Grabe, W. (2009). Reading in a second language: Moving from theory to practice. Cambridge University Press.

Gunn, B., Smolkowski, K., Biglan, A., Black, C., \& Blair, J. (2005). Fostering the Development of Reading Skill Through Supplemental Instruction: Results for Hispanic and NonHispanic Students. The Journal of Special Education, 39(2), 66-85. http://doi.org/10.1177/00224669050390020301 
Heyer, S. (1996). True Stories in the News: A Beginning Reader (2 ${ }^{\text {nd }}$ edition). Addison

Wesley Longman Publishing Company.

Hou, Y. (2018). Integration of Kahoot into EFL Classroom. In C. Stephanidis (Ed.), HCI International 2018 - Posters' Extended Abstracts (Vol. 852, pp. 31-37). https://doi.org/10.1007/978-3-319-92285-0_5

Huang, S. (2015). Mixed-method research on learning vocabulary through technology reveals vocabulary growth in second-grade students. Reading Psychology, 36(1), 1-30. https://eric.ed.gov/?id=EJ1042778

Lin, Debbita Tan Ai, and Manjet Kaur. (2018). "Kahoot! It: Gamification in Higher Education." 18. https://www.researchgate.net/publication/320182671_Kahoot_It_Gamification_in_Highe r_Education

Ismail, M. \& Mohammad, J. (2017). Kahoot: A promising tool for formative assessment in medical education. Education in Medicine Journal, 9(2), 19-26. https://doi.org/10.21315/eimj2017.9.2.2

Kondal, B., \& Prasad, V. (2016). Developing Language Skills Through MALL Among the Professional Students. 4(4), 6. https://www.researchgate.net/publication/294260160_Developing_Language_Skills_thro ugh_MALL_among_the_Professional_Students

Krashen, S. (1994). The input hypothesis and its rivals. In N. Ellis, (Ed.) Implicit and explicit learning of languages (p. 45-77). London: Academic Press

Krashen, S. (2003). Explorations in language acquisition and use: The Taipei lectures. Portsmouth, $\mathrm{NH}$ : Heinemann.

Krashen, S. (2004). The power of reading. Portsmouth, NH: Heinemann and Westport: Libraries Unlimited.

Krashen, S. (2009). Principles and Practice in Second Language Acqusition. Oxford: Pergamon Press.

Krashen, S. (2018). The Conduit Hypothesis: How Reading Leads to Academic Language Competence Language. Retrieved from http://www.sdkrashen.com/content/articles/2018_the_conduit_hypothesis.pdf

Kutner, M., Greenberg, E., Jin, Y., Boyle, B., Hsu, Y., \& Dunleavy, E. (2007). Literacy in everyday life: Results from the 2003 National Assessment of Adult Literacy (NCES 2007-480). Washington, DC: National Center for Education Statistics, Institute of Education Sciences, U.S. Department of Education.

Lee, C. (2017) The Research on the Learning Effect by integrating an Online Instant Response System into Earth Science Teaching-A Case Study for the Middle School Students from the Rural Area. Unpublished master's thesis, National Taiwan Normal University, Taipei, Taiwan.

Lee, K. (2008) Webquests in the english classroom: how do they affect student learning? Retrieved from https://cdr.lib.unc.edu/indexablecontent/uuid:1f08f80a-492f-44e6-b5ec6971541 ecce7

Licorish, S., Owen, H., Daniel, B., \& George, J. (2018). Students' perception of Kahoot!'s influence on teaching and learning. Research and Practice in Technology Enhanced Learning, 13(1), 9-31. https://doi.org/10.1186/s41039-018-0078-8 
Lieberman, D. What can we learn from playing interactive games? In: Vorderer, P., Bryant, J. (eds.) Playing Video Games: Motives, Responses, and Consequences, pp. 379- 397.

Lin, T. (2016). The Effect of Integrating Feedback and Signaling Design with Tablet IRS on College Students' Situational Interest and Attention. Unpublished master's thesis, National Chiao Tung University, Hsinchu, Taiwan

Lysenko, L., \& Abrami, P. (2014). Promoting reading comprehension with the use of technology. Computers and Education, 75, 162-172. https://doi.org/10.1016/j.compedu.2014.01.010

Mackay, S. (2010). Researching Second Language Classrooms. New York: Routledge.

Medina, E., \& Hurtado, C. (2017). Kahoot! A digital tool for learning vocabulary in a language classroom. Revista Publicando, 4(12), 441-449.

Mikhailov, S. (2001). Retrieved August, 2019, from http://www.ababasoft.com: http://www.ababasoft.com

Morgan, D. (1997). Focus groups as qualitative research (London: Sage).

National Reading Panel (NRP). (2000). Teaching children to read: An evidence-based assessment of the scientific research literature on reading and its implications for reading instruction (NIH Pub. No. 00-4754). Retrieved from. National Institute of Child Health \& Human Development Website http://www.nichd.nih.gov/publications/pubs/nrp/ pages/report.aspx.

Pede, J. (n.d.) "The Effects of the Online Game Kahoot on Science Vocabulary Acquisition." 51.

Pintrich, P. (2003). A motivational science perspective on the role of student motivation in learning and teaching contexts. Journal of Educational Psychology, 95,667-686. http://dx.doi.org/10.1037/0022-0663.95.4.667

Qiu, M., \& Bai, Z. (2013, March). http://219.142.121.14:8801/lunwen/files/ Papers/papergcce/141.pdf. Retrieved August, 28, 2019, from http://219.142.121.14:8801/.

RAND Reading and Study group (2002). Reading for Understanding. Toward an R\&D Program in Reading Comprehension. https://www.rand.org/pubs/monograph_reports/MR1465.html

Reynolds, R., Taylor, M., Steffensen, M., Shirey, L., \& Anderson, R. (1982). Cultural schemata and reading comprehension. Reading Research Quarterly, 17(3), 353366. https://doi.org/10.2307/747524

IEduNote (2017). Seven Reading Techniques for Increasing Learning \& Knowledge. https://www.iedunote.com/reading-techniques

Shanahan, T. (2005). Learning Point Associates/North Central Regional Educational Laboratory. Chicago: University of Illinois.

Snow, C. (2002). Reading for Understanding. Toward an R\&D program in Reading Comprehension. RAND Reading Study Group. Science and Technology Policy Institute.

Subramaniam, K. (2012). How webquests can enhance science learning principles in the $\begin{array}{llll}\text { classroom. } & \text { Clearing } & \text { House, } & \text { 85(6), }\end{array}$ http://dx.doi.org/10.1080/00098655.2012.698323

Wang, A., \& Lieberoth, A. (2016). The effect of points and audio on concentration, engagement, enjoyment, learning, motivation, and classroom dynamics using Kahoot. In T. Connolly \& L. Boyle (Eds.), Proceedings of the 10th European conference on game-based learning, reading (pp. 737-748). Reading, UK.

Wang, C. (2016). The Design and Implementation of Team-Game-Tournament with Instant Feedback System into a University Course. Unpublished master's thesis, Tamkang University, New Taipei City, Taiwan. 
Wang, Y. (2017). The effectiveness of integrating teaching strategies into IRS activities to facilitate learning: Interactive response system interventions. Journal of Computer Assisted Learning, 33(1), 35-50. https://doi.org/10.1111/jcal.12164

Wash, P. D. (2014). Taking advantage of mobile devices: Using Socrative in the classroom. Journal of Teaching and Learning with Technology, 3(1), 99-101. https://doi.org/10.14434/jotlt.v3n1.5016

Wells, J. (2011). Motivate students to engage in word study using vocabulary games. Intervention in School and Clinic, 45-49.

Wichadee, S., \& Pattanapichet, F. (2018). Enhancement of performance and motivation through intervention of digital games in an English language class. Teaching English with Technology, 18(1), 77-92.

Wolf-Wendel L., Ward K. and Kinzie J. (2009) A tangled web of terms: The overlap and unique contribution of involvement, engagement, and integration to understanding college student success. Journal of College Student Development 50(4): 407-28. http://www.dx.doi.org/10.1353/csd.0.0077

Yang, T. (2017). An Elementary Educational Study on Chinese Stroke Real-Time Response System. Unpublished master's thesis, National Taichung University of Education, Taichung, Taiwan.

Young, E. (2005). The Language of Science, the language of students: Bridging the gap with engaged learning vocabulary strategies. Science Activities, 42(2),12-17.

Zimmerman, B. \& Schunk, D. (2011). Self-regulated learning and performance: an introduction and overview. In B. J. Zimmerman, \& D. H. Schunk (Eds.), Handbook of self- regulation and performance (pp. 1-12). New York: Routledge.

Zarzycka-Piskorz, E. (2016). Kahoot it or not? Can games be motivating in learning grammar? Teaching English with Technology, 16(3), 17-36.

\section{Annexes}

\section{Focus group interview}

Question one

During the study, were the presented stories interesting for you?

Question Two

Do you consider that the digital format of the stories was suitable during the study? Why?

Question Three

What was your opinion about the Kahoot! methodology to improve the reading comprehension of stories in English?

Question Four

Which aspect did you like more about Kahoot!?

Question Five

What difficulties did you find during the application of Kahoot!?

Question Six 
The study had two moments: one in which the researcher prepared the questions beforehand, and the second one where groups were formed and the questions were elaborated by themselves. Which of the two moments did you prefer and why?

Question Seven

Do you think that Kahoot! helped you improve your reading comprehension in English? Why? Question Eight

What suggestions and recommendations would you give in case a similar study would take place in the future? 